\title{
Expression analysis of Argonaute genes in maize (Zea mays L.) in response to abiotic stress
}

\author{
Lihong Zhai ${ }^{1}$, Feng Teng ${ }^{1}$, Kangpeng Zheng ${ }^{1}$, Juan Xiao ${ }^{1}$, Wenbin Deng ${ }^{1}$ and Wei Sun ${ }^{2 *}$
}

\begin{abstract}
Background: Argonaute (AGO) protein is a kind of RNA binding protein that plays an integral role in the gene-silencing pathways guided by small RNAs. But there are few studies about the regulation of AGO genes responded to diverse abiotic stress in maize.

Results: In this study, we analyzed the expression of seventeen ZmAGO genes under heat, cold, salinity, drought and ABA treatments using quantitative PCR (qPCR). All ZmAGOs showed differential expression modes under various abiotic stress treatments. Two ZmAGOs ( $Z m A G O 1 a$ and $Z m A G O 5 d$ ) and other fifteen ZmAGOs exhibited specific up-regulation in response to heat separately. Several $Z m A G O$ genes are very sensitive to cold stress, but many $Z m A G O$ genes are slow to respond to $\mathrm{NaCl}$ treatment. Nine ZmAGO genes (ZmAGO1f, ZmAGO2b, ZmAGO4, ZmAGO5a/b/c, ZmAGO7, ZmAGO9 and $Z m A G O 18 a / b)$ presented definite up-regulation in response to drought, which were similar to the pattern of gene regulation under abscisic acid (ABA) treatment.
\end{abstract}

Conclusions: Various $Z m A G O$ genes respond to different abiotic stress treatments. These results provide fundamental information and insights for the further study on the role of abiotic stress resistance genes in maize and provide basis for further study on the function of AGO genes in response to abiotic stress in maize.

\section{Background}

Global climate change threatens crop yield by imposing ambient pressures such as cold, drought, salinity, heat and other abiotic and biotic stresses [1]. Numerous studies indicate that small RNAs (sRNAs) have important roles in gene expression regulation during the abiotic and biotic stresses in all plants [2-6]. Argonaute (AGO) proteins are the key effectors of the RNA-induced silencing complex (RISC). The small RNAs are categorized to bind to specific AGO family proteins which then guide RISC to silence their targets through complementary base paring. Typical functions of plant RISCs include the target RNAs endonucleolytic cleavage or translational inhibition and the target DNAs methylations $[7,8]$.

In plants, different species encode different numbers of AGO family members. Arabidopsis possesses 10

\footnotetext{
* Correspondence: Starking521@webmail.hzau.edu.cn

${ }^{2}$ College of Agriculture and Biology, Zhongkai University of Agriculture and

Engineering, Guangzhou 510225, People's Republic of China

Full list of author information is available at the end of the article
}

AGOs [9], whereas there are 17 in maize [10] and 19 in rice [11]. Phylogenetically, plants AGOs are divided into three major groups: AGO1/5/10, AGO2/3/7 and AGO4/ 6/8/9. In addition, the grass-specific AGO18 family has an important role in viral defense and plant reproduction [12, 13]. A series of studies of ago $1 \mathrm{mu}-$ tants indicated that AGO1 has a role in leaf polarity [14] and lateral organ development [15] of Arabidopsis, and that AGO1 plays a role in carrying out the function of most miRNAs [16]. Furthermore, AtAGO1 also functions to effectively clean up viral RNAs $[17,18]$. Recent research showed that AtAGO1 binds to chromatin to promote gene expression in response to plant hormones and stresses [19]. In addition, AGO1 also interacts with chromatin at MIR161 and MIR173 loci and leads to the disassembly of the transcriptional complex, releasing short and unpolyadenylated transcripts under salt stress conditions [20]. AtAGO10 functions in inflorescence meristem and shoot apical meristem development through completely binding to miR165/166 with AtAGO1 and jointly binding to miR172 to enhance the

(C) The Author(s). 2019 Open Access This article is distributed under the terms of the Creative Commons Attribution 4.0 International License (http://creativecommons.org/licenses/by/4.0/), which permits unrestricted use, distribution, and reproduction in any medium, provided you give appropriate credit to the original author(s) and the source, provide a link to the Creative Commons license, and indicate if changes were made. The Creative Commons Public Domain Dedication waiver (http://creativecommons.org/publicdomain/zero/1.0/) applies to the data made available in this article, unless otherwise stated. 
function of AtAGO1, respectively [21-23]. Different from AtAGO1 and AtAGO10, it was discovered that AtAGO5 expressed around reproductive cells during megasporogenesis, and ago5 mutants exhibited deficiencies in the initial stage of megagametogenesis [24]. Recent research showed that AtAGO5 expression is induced by Potexvirus infection and that both AtAGO2 and AtAGO5 are needed to completely limit PVX infection in Arabidopsis [25].

AtAGO2 is found to play a key role in pathogen defense and DNA repair [26-29]. Although AtAGO3 and AtAGO2 are tandem repeat genes, AtAGO3 cannot act redundantly with AtAGO2 in pathogen defense. However, AtAGO3-associated sRNAs are similar in that they all bind to AtAGO4, suggesting that AtAGO3 participates in plant DNA methylation [30]. AtAGO7 plays an essential role in accelerating the phase change from juvenile to adult stage, and also takes part in the TAS3-based tasiRNA biogenesis [31]. In addition, like AtAGO1, AtAGO7 participates in pathogen defense [17].

AtAGO4 and AtAGO6 bind to different RNA polymerases to carry out RNA-induced DNA methylation orderly [32]. Meanwhile, AtAGO6 also plays a role in transcriptional gene silencing which mediated by RNA in shoot and root meristems [33]. Moreover, AtAGO4 is involved in virus resistance [34, 35]. AtAGO8 is considered as a pseudogene [36] and has no homologous gene in rice and maize. Recently, it was found that AGO8 mediated the induction of primary defense against herbivory in Nicotiana attenuata [37]. Nevertheless, AtAGO9 regulates germ cell fate by a noncell autonomous sRNA pathway [38, 39].

Viral-inducible OsAGO18 sequesters miR168 to ease the repression of rice OsAGO1 by miR168 to enable antiviral defense in the infected rice [40]. OsAGO18 also competes with OsAGO1 for binding to miR528, resulting in the release of the negative regulation of $\mathrm{AO}$ gene by OsAGO1-miR528, and then boosts the ROS accumulation to trigger the pathogen defense pathway [41]. However, high level of specific expression of ZmAGO18 in the tapetum and germ cells of maize meiotic anthers [10] is implicated that $\mathrm{ZmAGO18}$ is a negative regulator to determine the inflorescence and axillary meristems by interacting with the regulatory pathway of miR166-HDZIP III TF [13]. The expression pattern of ZmAGO1a under five different abiotic stresses indicated that $Z m A$ GO1a might play an important role in both development and responses to environmental change as a member of the AGO gene family in maize [42]. Therefore, AGO genes function in the development and pathogen defense of plants, and AGO genes would be up- or down-regulated under virous abiotic stress in rice $[11,43]$ and cucumber [1].
In this study, we analyzed the differential expressions of $17 \mathrm{ZmAGOs}$ in maize under various abiotic stress treatments, and explored potential drought resistance function of ZmAGO18b, which provided a basis for further understanding and study the stress tolerance mechanism of this important crop.

\section{Results and discussion}

\section{Expression patterns of ZmAGO genes under heat stress}

To investigate the heat stress-responsiveness of $Z m A G O$ genes in maize, we transferred the whole maize seedlings into an incubator at $40^{\circ} \mathrm{C}$ and then sampled at the six different points $(0,0.5,1,2,4$, and $12 \mathrm{~h})$. The results showed that all $Z m A G O s$ responded to heat stress.

It was found that 10 (ZmAGO1f, ZmAGO2b, ZmAGO4, ZmAGO5a/b/c, ZmAGO7, ZmAGO9, ZmAGO10b and $Z m A G O 18 a)$ of the 17 genes were upregulated by this treatment at $1 \mathrm{~h}$ and then declined at $2 \mathrm{~h}, 4 \mathrm{~h}$ and $12 \mathrm{~h}$ (Fig. 1a). Among these 10 genes, $Z m A G O 2 b$ and $Z m A G O 5 a$ were relatively upregulated strongly at $1 \mathrm{~h}$ after treatment. Interestingly, $Z m A$ GO1b/c, ZmAGO2a, ZmAGO10a and ZmAGO18b were upregulated and then downregulated at $2 \mathrm{~h}$ after heat treatment (Fig. 1b), indicating that each AGO gene has its own function which regulates gene expression in different time periods during abiotic stress. In addition, ZmAGO1a and ZmAGO5d were downregulated relative to control treatment (Fig. 1c).

Expression profiling of ZmAGOs in response to cold stress For cold stress, we examined the expression levels of ZmAGO genes in whole seedlings at the six different points $(0,0.5,1,2,4$, and $12 \mathrm{~h})$ under $4{ }^{\circ} \mathrm{C}$ treatment using qPCR. The results of the relative expression levels of the cold-treated samples are shown in Fig. 2.

Compared to the control, ZmAGO5d, ZmAGO7 and ZmAGO10a were downregulated (Fig. 2d), other $Z m A G O s$ were upregulated in varying degrees by this treatment. The expression of ZmAGO1c, ZmAGO2a, $Z m A G O 5 a$ and $Z m A G O 5 c$ were upregulated up to $0.5 \mathrm{~h}$ after the cold treatment and then declined gradually at 1, 2, 4 and $12 \mathrm{~h}$ (Fig. 2a). ZmAGO1a, ZmAGO1b, ZmAGO1f, ZmAGO4, ZmAGO9 and $Z m A G O 10 b$ increased slightly up to $1 \mathrm{~h}$ after treatment and downregulated thereafter (Fig. 2b). $Z m A$ GO2b, ZmAGO5b, ZmAGO18a and ZmAGO18b were downregulated at $0.5 \mathrm{~h}$ after treatment but then were upregulated at $1 \mathrm{~h}$, followed by a decrease at $2 \mathrm{~h}, 4 \mathrm{~h}$ and $12 \mathrm{~h}$ (Fig. 2c). The results showed that almost all $Z m A G O s$ were responsive to low temperature. Furthermore, the expression level of all $Z m A G O s$ was very low at $4 \mathrm{~h}$ after treatment, indicating that maize could resist low temperature for $4 \mathrm{~h}$ through various gene expressional regulation. 


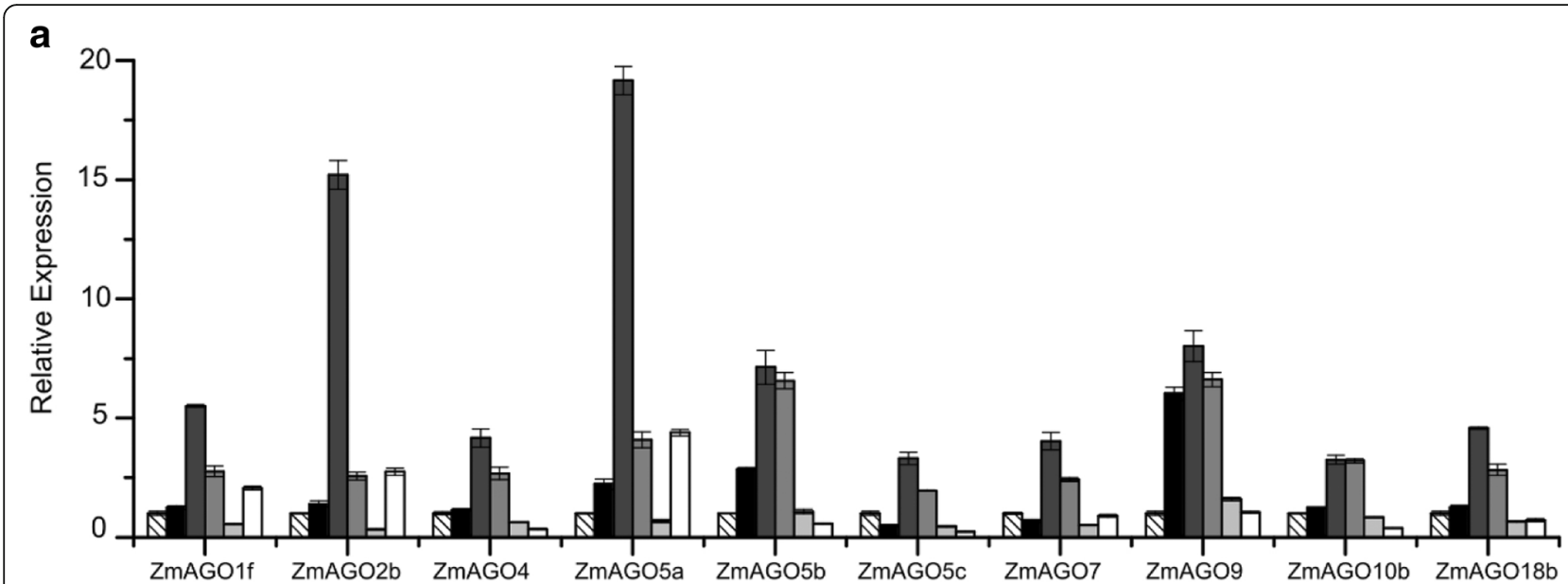

b

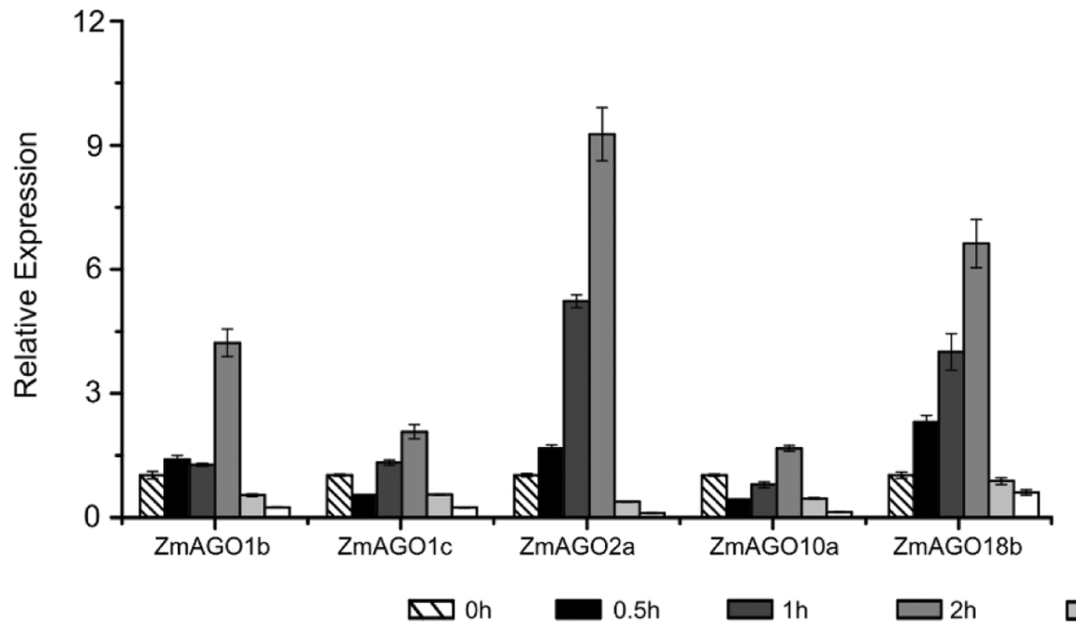

(c)

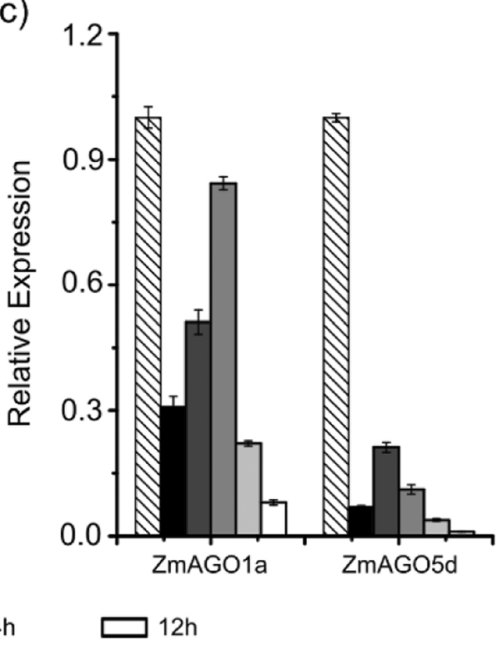

Fig. $1 \mathrm{qPCR}$ analysis of $\mathrm{ZmAGO}$ genes expression in response to $40^{\circ} \mathrm{C}$ treatment at $0,0.5,1,2,4,12 \mathrm{~h}$ of treatment. $\mathrm{ZmActin}$ normalizes the data as an internal control. Y-axis represents relative expression levels

\section{Expression analysis of ZmAGO genes by qPCR under $\mathrm{NaCl}$} treatment

To discover the responsiveness of $\mathrm{ZmAGO}$ genes to $\mathrm{NaCl}$ treatment, the seedling roots were submerged in a solution of $0.2 \mathrm{M} \mathrm{NaCl}$, and the whole seedlings were sampled at $0,0.5,1,2,4$, and $12 \mathrm{~h}$ after treatment.

Eight genes $(\mathrm{ZmAGO1a} / \mathrm{c}, \mathrm{ZmAGO5b/c/d}$, $Z m A G O 7$ and $Z m A G O 10 a / b)$ out of 17 were downregulated slightly by $\mathrm{NaCl}$ treatment (Fig. 3b). ZmAGO1b/f, ZmAGO2b, ZmAGO4, ZmAGO5a, $Z m A G O 9$ and $Z m A G O 18 a$ genes were slightly upregulated until $4 \mathrm{~h}$ after $\mathrm{NaCl}$ treatment and were downregulated at $12 \mathrm{~h}$ after $\mathrm{NaCl}$ treatment. But $\mathrm{ZmAGO} 2 a$ was upregulated slightly up to 4 and $12 \mathrm{~h}$ after $\mathrm{NaCl}$ treatment. On the contrary, $\mathrm{ZmAGO18b}$ was upregulated at 0.5 and $1 \mathrm{~h}$ after $\mathrm{NaCl}$ treatment and then declined at 2, 4, and $12 \mathrm{~h}$ (Fig. 3a). Altogether, the results showed that all ZmAGOs were slightly responsive to $\mathrm{NaCl}$ stress.

\section{Responses of ZmAGOs to drought stress}

For drought stress, we pulled the seedling roots out of the soil without water supply, and the whole seedlings were sampled at $0,0.5,1,2,4$, and $12 \mathrm{~h}$ after drought treatment. The expression analysis showed that all ZmAGO genes were induced to response to the drought treatment.

According to the response to drought stress, ZmAGO genes can be divided into two categories which are slightly and strongly induced group. $Z m A$ GO1a/b/c, ZmAGO10a/b, ZmAGO5d and ZmAGO2a were upregulated slightly at $1 \mathrm{~h}$ after the drought stress and then decreased at 2, 4 and $12 \mathrm{~h}$ (Fig. 4a). Ten (ZmAGO1f, ZmAGO4, ZmAGO5a/b/c,

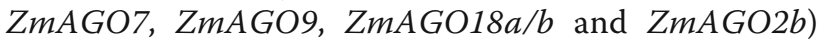
of the 17 genes were significantly upregulated by drought treatment at $1 \mathrm{~h}$ and then declined at 2, 4 and $12 \mathrm{~h}$ (Fig. 4b). It should be emphasized that ZmAGO18a (539.9-fold upregulated compared to the 


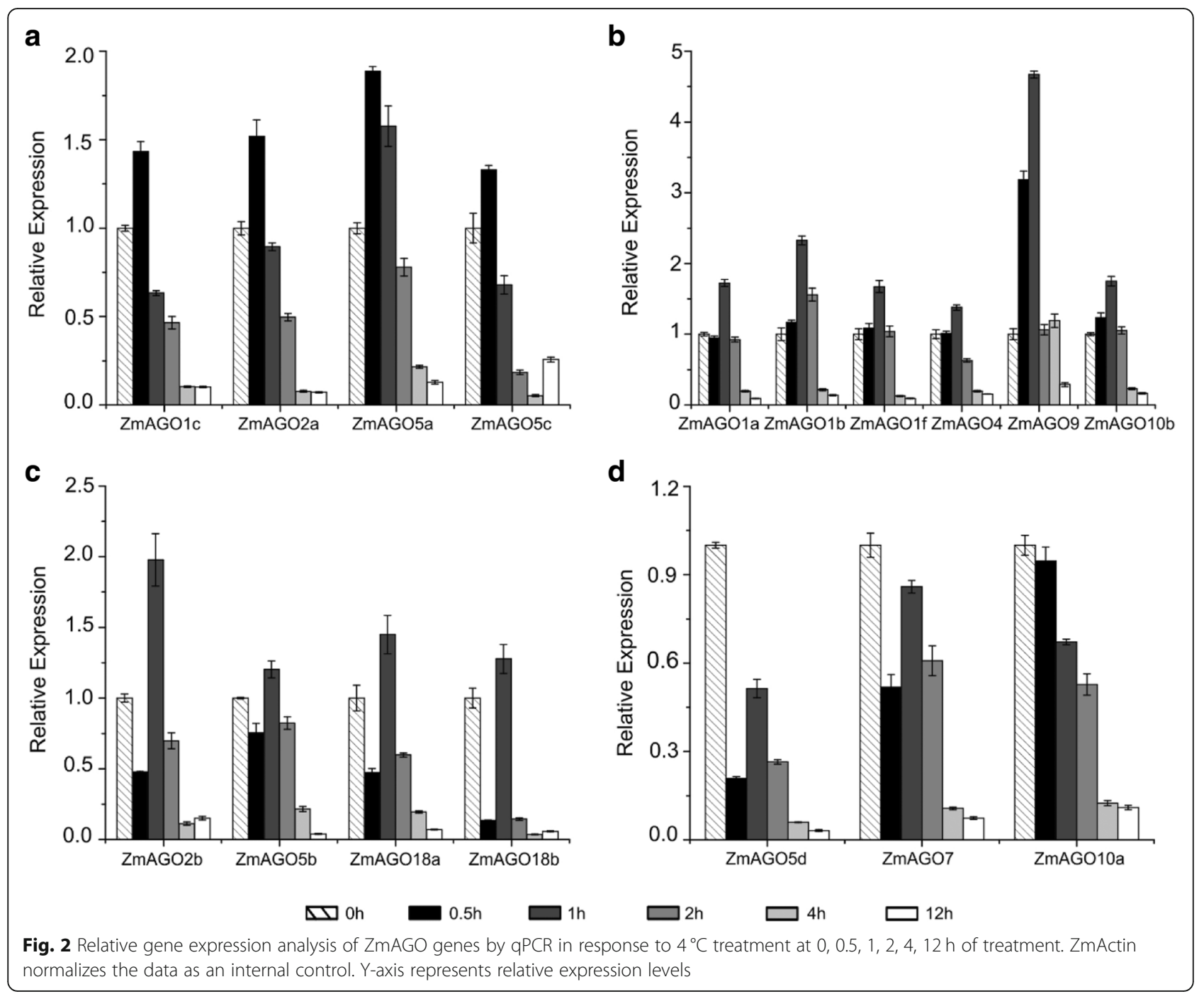

control) and ZmAGO18b (730.8-fold upregulated compared to the control) were highly induced at $1 \mathrm{~h}$ under the drought stress, indicating that the $\mathrm{ZmA}$ GO18a/b plays important roles in gene regulation during the drought stress.

\section{The expression pattern of $\mathrm{ZmAGO}$ genes under $\mathrm{ABA}$ treatment}

To discover the responsiveness of in maize to $\mathrm{ABA}$ treatment, we investigated the transcript levels of $Z m A G O$ genes in maize whole seedlings under $\mathrm{ABA}$ treatment by $\mathrm{qPCR}$. Interestingly, we found that ZmAGO genes responded to the ABA treatment in a time-dependent manner.

$\mathrm{ZmAGO4}$ and $\mathrm{ZmAGO5b/c}$ were upregulated slightly up to $1 \mathrm{~h}$ after the ABA treatment and then decreased at 2, 4 and $12 \mathrm{~h}$ (Fig. 5a). ZmAGO2b, ZmAGO5a, $Z m A G O 7, Z m A G O 10 b$ and $Z m A G O 18 a$ were upregulated gradually at $0.5,1$ and $2 \mathrm{~h}$ and then declined at 4 and $12 \mathrm{~h}$. Meanwhile, the highest expression level of $\mathrm{ZmAGO18b}$ was at $4 \mathrm{~h}$ after the ABA treatment and then declined at $12 \mathrm{~h}$ (Fig. 5b/d). In the end, ZmAGO1a/ $b / c / f$ and $Z m A G O 9$ were maximized induced expression at $12 \mathrm{~h}$ (Fig. 5c). But beyond that, ZmAGO2a, ZmAGO5d and ZmAGO10a were slightly downregulated by the ABA treatment compared to the control (Fig. 5d).

In eukaryotic sRNA-based gene silencing pathways, AGO proteins are effectors which function in gene expression regulation and chromatin modification. The majority of studies about plant AGOs revealed their function in plant development and pathogen defense. Some studies reported that plant AGO genes also respond to abiotic stresses. In Oryza sativa, nine of 19 OsAGOs (OsAGOla/b/c/d, OsAGO2, OsA$G O 4 a / b$, OsPNH1 and OsAGO16) were upregulated in response to salt, cold and dehydration stresses by microarray-based expression analysis. The samples were collected the 7 days-seedlings which were treated 


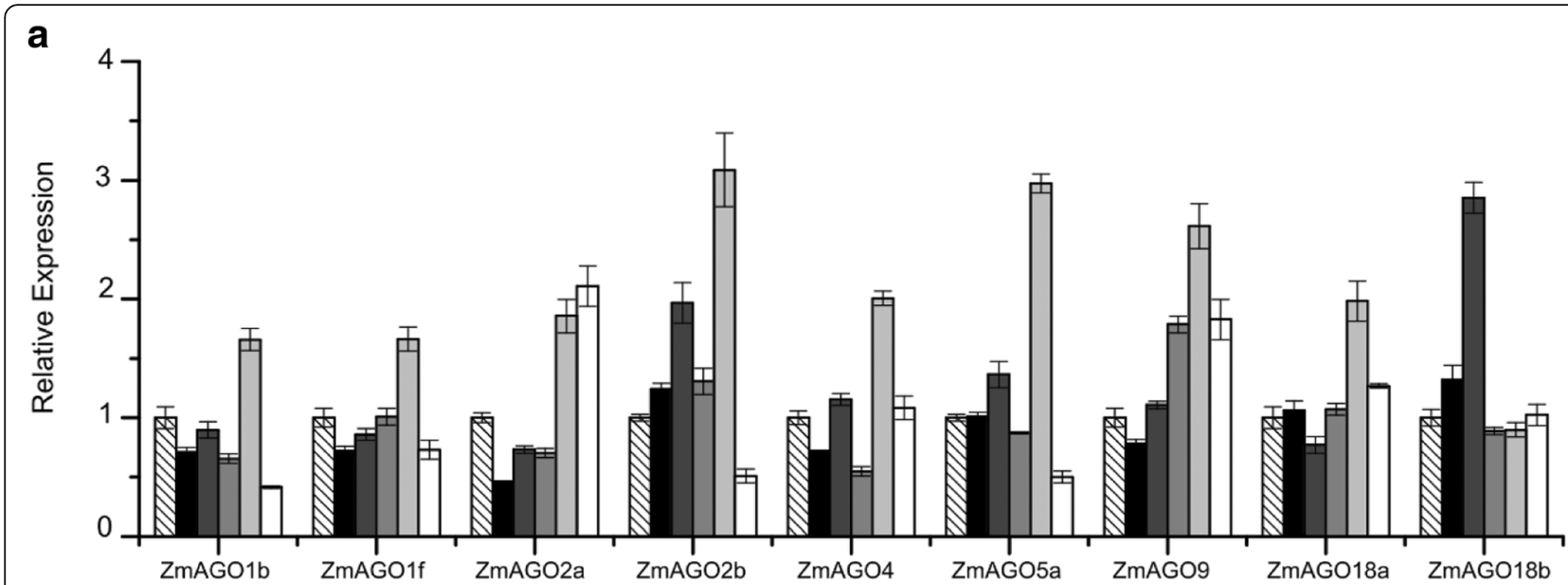

b

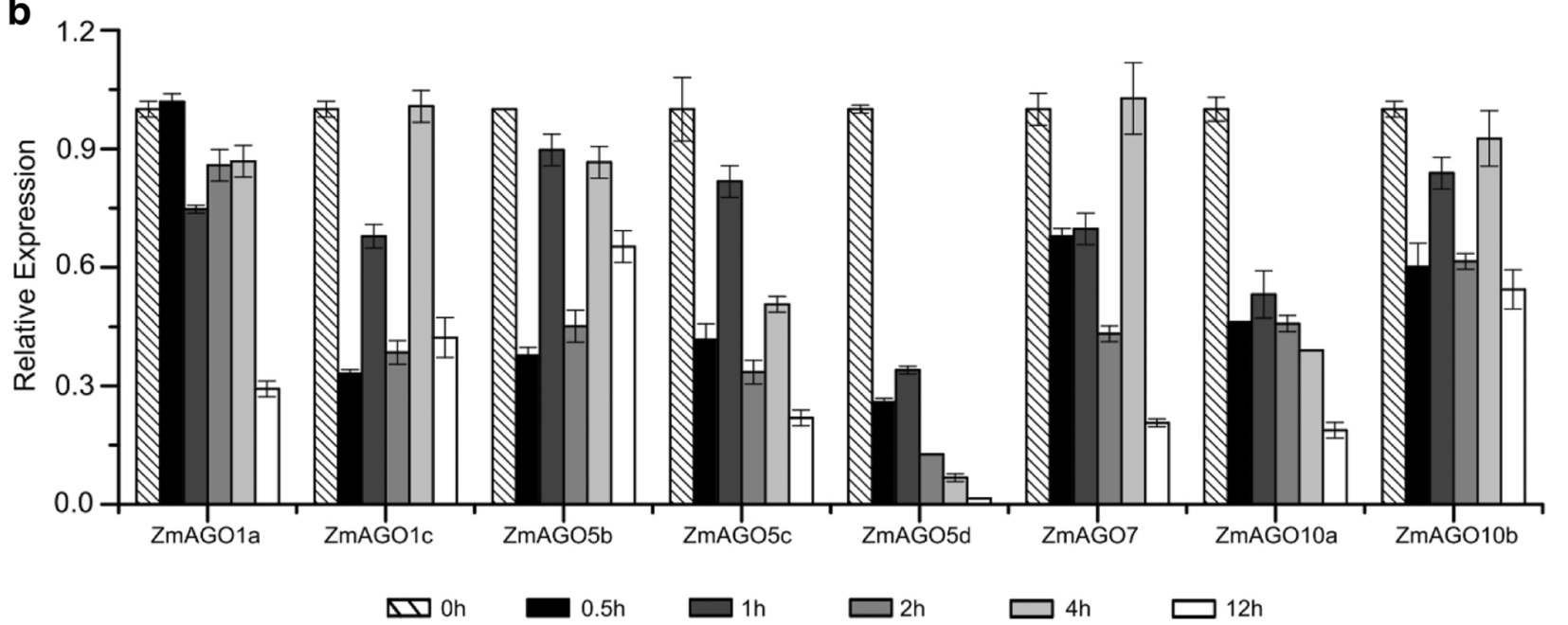

Fig. 3 qPCR expression analysis of ZmAGO genes in response to $\mathrm{NaCl}$ treatment at $0,0.5,1,2,4,12 \mathrm{~h}$ of treatment. ZmActin normalizes the data as an internal control. Y-axis represents relative expression levels

$3 \mathrm{~h}$ by the above three stresses [11]. But in the current study, all $17 \mathrm{ZmAGOs}$ were downregulated at $4 \mathrm{~h}$ after the cold treatment compared to the control. ZmAGO1b/f, ZmAGO2b, ZmAGO4, ZmAGO5a, ZmAGO9 and ZmAGO18a genes were slightly upregulated until $4 \mathrm{~h}$ after salt treatment. Another study about OsAGOs expression analysis indicated that six OsAGO genes (OsAGO1a/d, OsAGO3, OsAGO7, OsAGO13 and OsAGO16) were up or down-regulated in response to one or more of the phytohormone 1Naphthaleneacetic acid (NAA), Kinetin (KT) and Gibberellin A3 (GA3) in seedlings at trefoil stage [43]. Furthermore, these six OsAGOs were sensitive to different hormones and differences existed among varieties [43]. In the present study, 14 out of 17 ZmAGOs were sensitive to $\mathrm{ABA}$ and these genes responded to the ABA treatment temporally. Interestingly, the recent research illustrated that AtAGO1 is responsive to hormones and cold stress and triggered by these stimuli to bind to stimuli-responsive genes [19]. In addition to the classical RNAi mechanism, it is suggested that plant AGO genes might facilitate the induction of genes in virous stimuli signaling pathways and the activation of the stimuli responses.

Notably, monocots-specific AGO18 gene is distinctive. OsAGO18 and ZmAGO18 exhibited high level expression during reproductive stage. Whereas OsAGO18 participates the process of pathogen defense [41], ZmAGO18b specifically expresses in meiotic anthers [10] and plays an crucial role in the determinacy of inflorescence and axillary meristems [13]. In this study, ZmAGO18a and ZmAGO18b were significantly reduced in seedlings by drought treatment. This result demonstrates the importance of ZmAGO18s during the drought stress. Further studies should be carried out to investigate mechanisms of the ZmAGO18s function in drought stress, and to provide new insights into the drought resistance. 


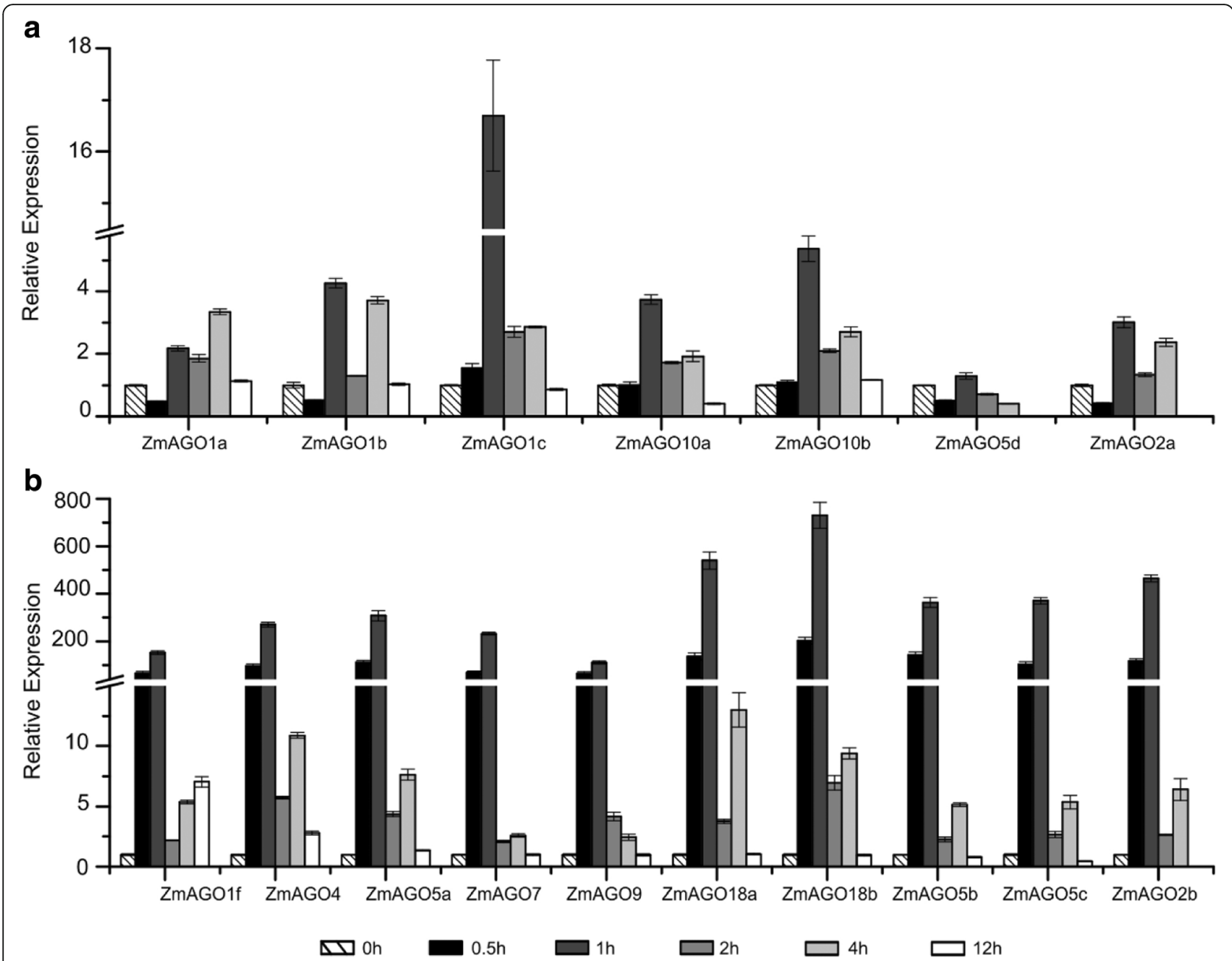

Fig. 4 Expression analysis of $Z m A G O$ genes by qPCR in response to drought treatment at 0, 0.5, 1, 2, 4, $12 \mathrm{~h}$ of treatment. ZmActin normalizes the data as an internal control. Y-axis represents relative expression levels

Stress responsive elements in the promotor of $\mathrm{ZmAGO}$ genes and the phenotype of ZmAGO18b mutant after drought treatment

Several cis-acting elements related to plant development and response were identified, implicating the possible involvement of AGO gene family in development and stress tolerance (Additional file 1: Table $\mathrm{S} 1$ ). We selected two typical stress responsive elements (STRE and TC-rich repeats) and one ABA responsive element (ABRE) to demonstrate the distribution of cis-acting elements in the promotor region (Fig. 6).

As shown in Fig. 6, STRE element is abundant in promotor region of the majority of AGO gene family. In addition, we found that genes with the same expression pattern are likely to have similar elements. For example, $\mathrm{ZmAGO18b}$ and $\mathrm{ZmAGO5a}$ were specifically expressed in meiotic tassel [10] and they were all responsive to drought and heat in this study, and the largest number of STRE elements were distributed in their promotor region, 8 and 12, respectively. These data suggested that these genes might have potential function of resistance to stress during the meiosis of tassel. ZmAGO1f and $Z m A G O 10 b$ are highly expressed in immature tassel, and they have unique TC-rich repeats element. The ABA-insensitive genes (ZmAGO1a/b, ZmAGO2a, ZmAGO5d and $Z m A G O 10 a / b)$ have fewer ABRE, but not all. To further determine the drought response of $\mathrm{ZmA}$ GO18b gene, we observed the phenotype of Mutate-mediated mutant of ZmAGO18b (ago18b:mum) described previously [13]. The results showed that the mutant leaves displayed more severe yellowing after $24 \mathrm{~h}$ of drought treatment (Fig. 7), indicating the drought resistance function of $\mathrm{ZmAGO18b}$ gene. We will further study the drought resistance mechanism of ZmAGO18b gene. 


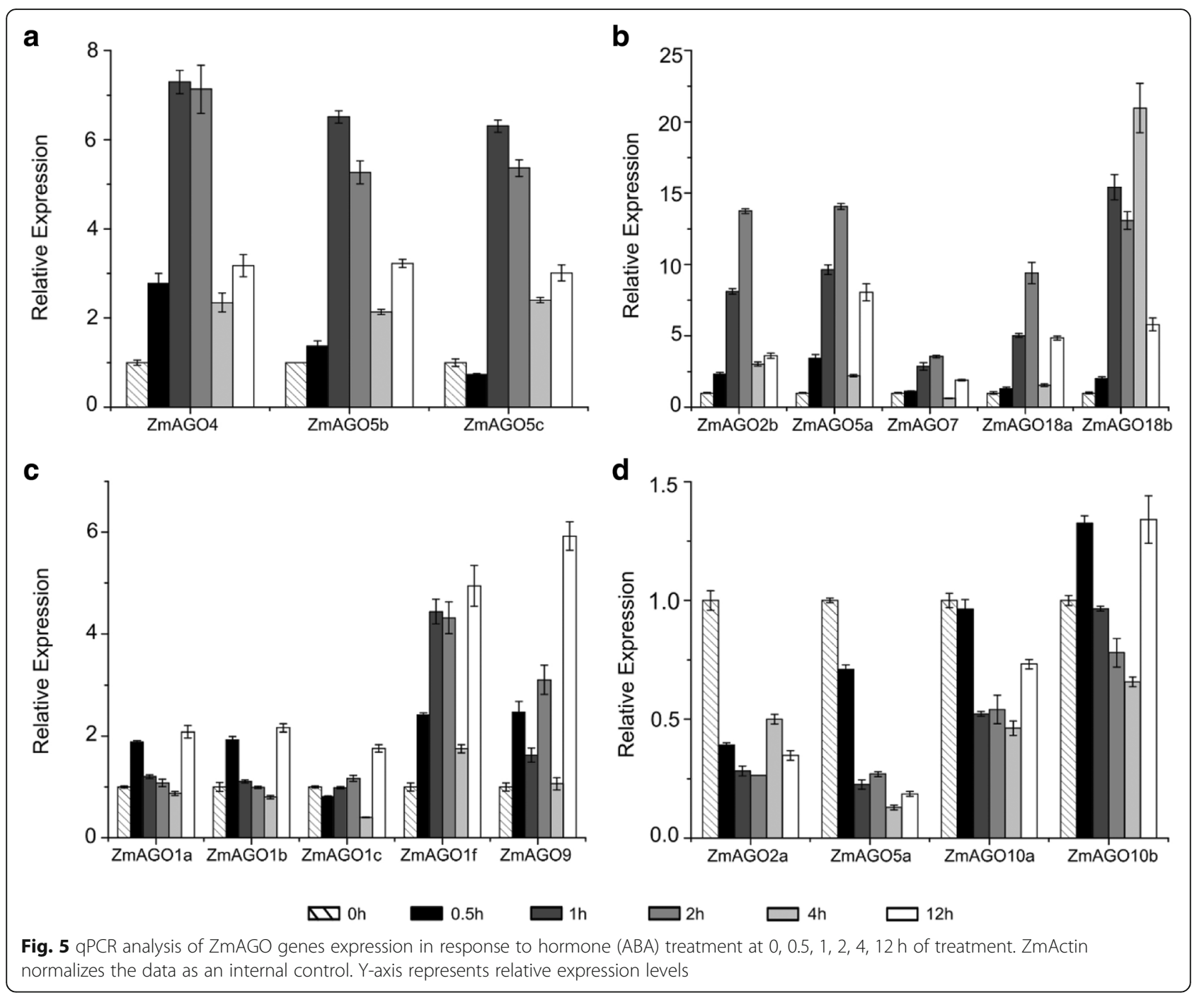

\section{Conclusions}

In summary, this work is the first report on expression analysis of all ZmAGO genes in maize under heat, cold, salt, drought and ABA stress treatments. We discovered that various $Z m A G O$ genes respond to different abiotic stress treatments. And ZmAGO18b may have potential drought resistance function, which prompts us to further study its drought resistance mechanism. According to results of the present study, it should consider as a basis for intensive functional research of ZmAGO genes during abiotic stress.

\section{Materials and methods}

Plant materials and treatments

Seeds of maize (Zea mays L. cvB73) were grown in potting soil under greenhouse conditions at $25^{\circ} \mathrm{C}$ with an 8 $\mathrm{h}$ dark and $16 \mathrm{~h}$ light (Department of Molecular Biology of Hubei University of Arts and Science, Xiangyang, China). Two-week-old seedlings growing synchronously were selected to impose different abiotic stress treatments, which including heat, cold, salinity, drought and abscisic acid (ABA). Gene expression was analyzed at different time points of treatments $(0,0.5,1,2,4$, and $12 \mathrm{~h})$. We select three individual and whole seedlings as three independent biological replicates at each treatment point. For cold and heat treatments, potted maize seedlings were respectively incubated at $4{ }^{\circ} \mathrm{C}$ and $40^{\circ} \mathrm{C}$. Salinity treatment was applied by submerging seedling roots in a $0.2 \mathrm{M} \mathrm{NaCl}$ solution. To impose the drought treatment, we gently pulled the whole maize seedlings out of the soil. In order to remove the adhering soil, we washed their roots carefully with fresh water. Then the seedlings were incubated on a dry paper towel at $25^{\circ} \mathrm{C}$, water was not supplied throughout the treatment process. For ABA treatment, seedlings roots were submerged in a solution of $0.1 \mathrm{mM}$ ABA. Rapid freezing of samples with liquid nitrogen and preservation at $-80^{\circ} \mathrm{C}$ for RNA isolation. 


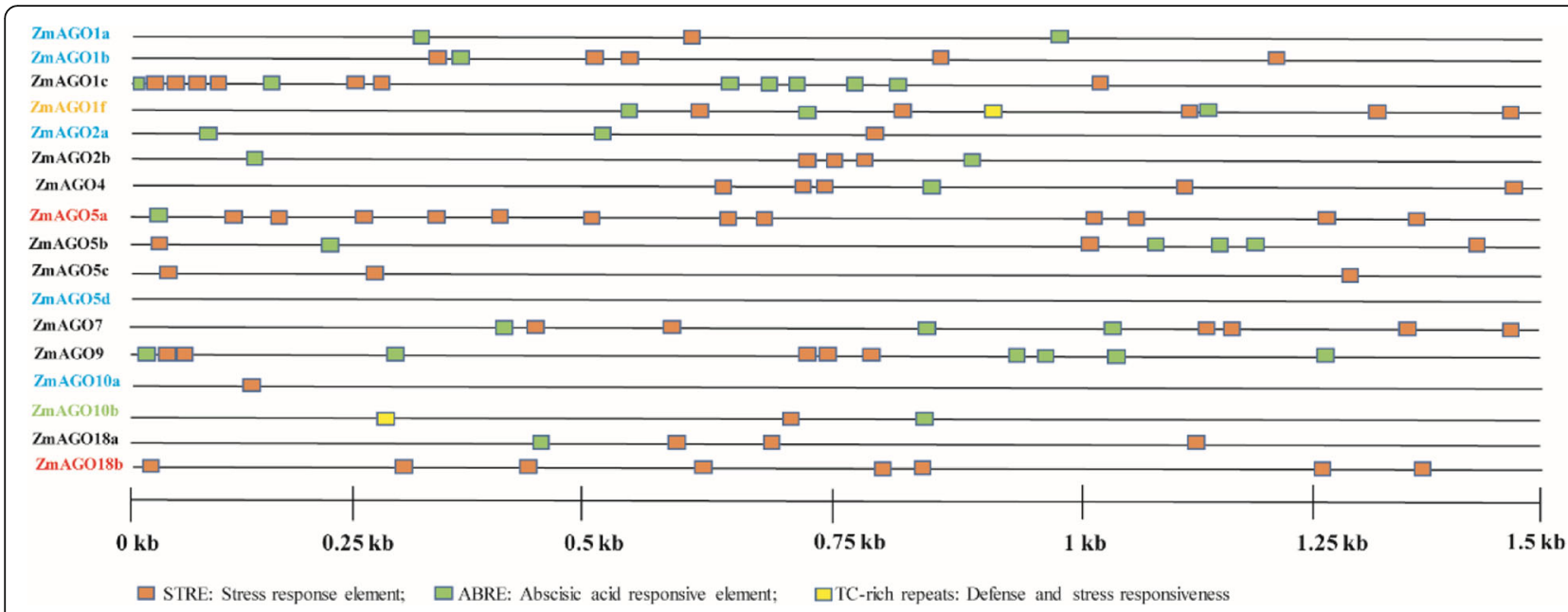

Fig. 6 Typical stress and ABA-responsive elements location of ZmAGO gene family

Seeds of W22 and Mutate-mediated mutant of ZmAGO18b (ago18b:mum) which described in the previous study [13] were also grown under the conditions described above for drought treatment. The phenotype of these materials after drought treatment for $24 \mathrm{~h}$ were observed.

\section{RNA extraction and qPCR}

Total RNA from the different stress treated samples was extracted using Trizol (Invitrogen, Carlsbad, CA, USA). Genomic DNA contaminants were removed from the RNA by treating the RNA with DNaseI (TaKaRa Biotech,
Dalian, China). A Qubit 2.0 (Invitrogen) was used to measure the RNA concentration in each sample. An oligo (dT) primer and M-MLV (Invitrogen) reverse transcriptase was used to synthesize first-strand cDNAs from RNA following the manufacture's protocol.

Gene-specific primers reference to previous described for the qPCR expression analysis [10]. ZmActin (NM_001155179) was used as the internal control and was amplified with the primers $5^{\prime}-$ TACG AGATGCCTGATGGTCAGGTCA $-3^{\prime}$ and $5^{\prime}$ TGGAGTTGTACGTGGCCTCATGGAC - 3 '. QPCR was carried out on the Bio-RAD CFX96 using the

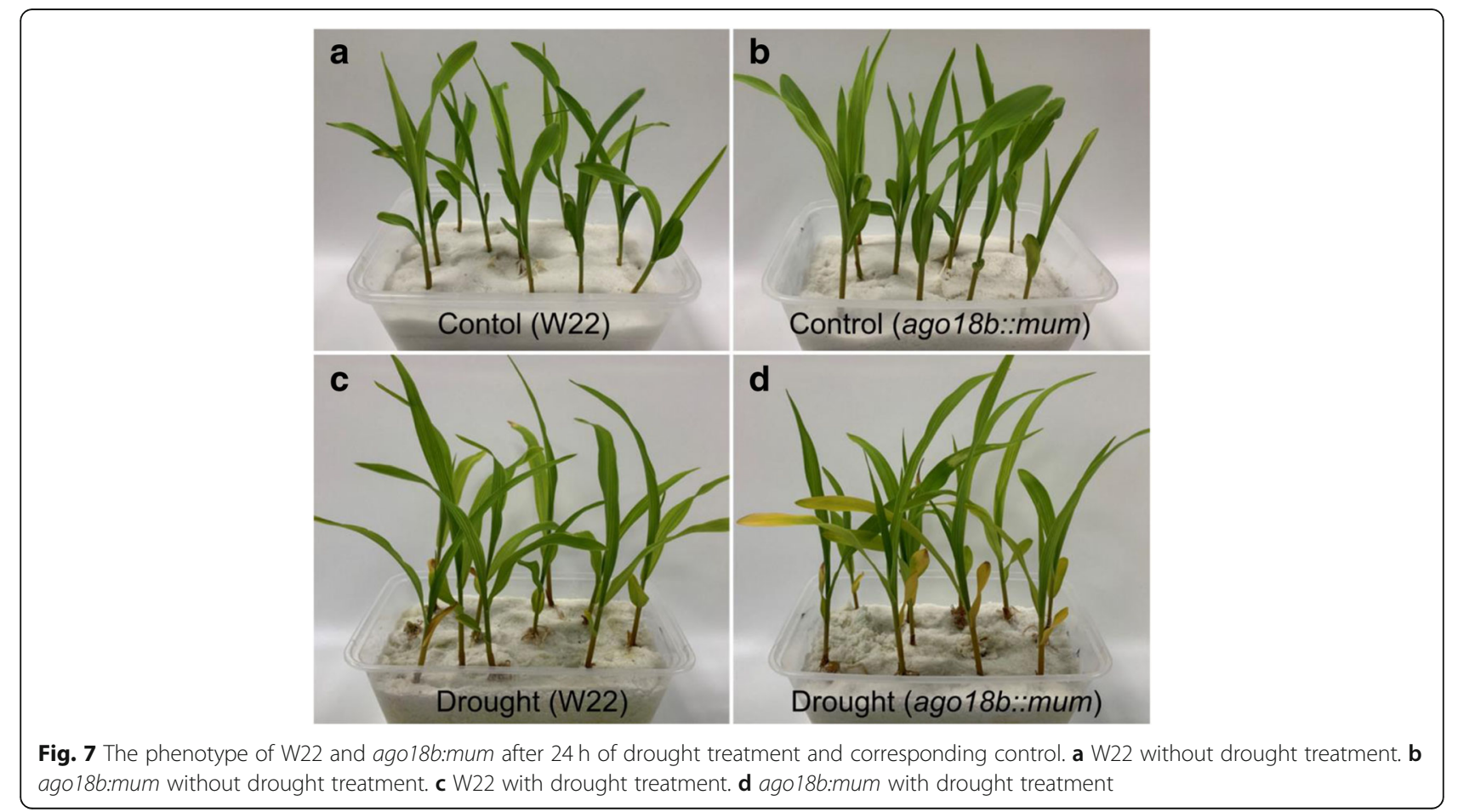


SYBR FAST qPCR Kit Master Mix (2x) LightCycler (KAPA, USA). The qPCR was conducted in $20 \mu \mathrm{L}$ reaction volumes consisting of $3.0 \mu \mathrm{L}$ diluted cDNA, $1.0 \mu \mathrm{L}$ forward and reverse primers $(10 \mu \mathrm{M}), 10 \mu \mathrm{L}$ SYBR FAST qPCR Kit Master Mix (2x) LightCycler (KAPA, USA) and $5 \mu \mathrm{L}$ double-distilled water. The qPCR conditions were as follows: pre-denaturation for $300 \mathrm{~s}$ at $95^{\circ} \mathrm{C}, 40$ cycles at $95^{\circ} \mathrm{C}$ for $10 \mathrm{~s}, 58^{\circ} \mathrm{C}$ or $60{ }^{\circ} \mathrm{C}$ for $20 \mathrm{~s}$. Three biological replicates were performed. The relative gene expression was calculated using the $2^{-\Delta \Delta C t}$ method [44] in the EXCEL software.

\section{Cis-regulatory elements analysis of ZmAGOs promotor}

To analyze the stress responsive elements of ZmAGO genes, we identified putative cis-regulatory elements of about 5 to $10 \mathrm{bp}$ in around 1500-bp upstream from the start codon (ATG) of $17 \mathrm{ZmAGO}$ genes using the PlantCARE web tool (http://bioinformatics.psb.ugent. be/webtools/plantcare/html/).

\section{Additional file}

Additional file 1: Table S1. Putative cis-elements of more than $5 \mathrm{bp}$ identified in 17 ZmAGO genes using PlantCARE database. (XLSX 64 kb)

\author{
Abbreviations \\ ABA: Abscisic acid; AGO: Argonaute; qPCR: Quantitative PCR; RISC: RNA-induced \\ silencing complex; ROS: Reactive oxygen species; sRNA: Small RNA; \\ tasiRNA: Trans-acting small interfering RNA
}

\section{Acknowledgements}

We thank Dr. Jun Huang for valuable advice on the manuscript.

\section{Consent to participate}

Not applicable.

\section{Authors' contributions}

All authors read and approved the final manuscript. LZ, WD and WS designed the study, WS, PZ, JX and FT performed the experimental work, FT grew the plants, PZ, JX and FT isolated the RNA and carried out the expression analysis, WS and LZ wrote the manuscript.

\section{Funding}

This work was supported by the National Natural Science Foundation of China (No. 31501320), the China Scholarship Council (201908420122), the Teachers' Scientific Ability Cultivation Foundation of Hubei University of Arts and Science (No. PYSB20181064), National Undergraduate Training Programs for Innovation and Entrepreneurship (201810519001), and Xiangyang Youth Science and Technology Talent development Plan.

\section{Availability of data and materials}

The datasets used and/or analysis in the current study can be obtained from the corresponding author according to reasonable requirements.

\section{Ethics approval}

Not applicable.

\section{Consent for publication}

Not applicable.

\section{Competing interests}

The authors declare that they have no competing interests.

\section{Author details}

'Medical College, Hubei University of Arts and Science, Xiangyang 441053, People's Republic of China. ${ }^{2}$ College of Agriculture and Biology, Zhongkai University of Agriculture and Engineering, Guangzhou 510225, People's

Republic of China.

Received: 16 February 2019 Accepted: 11 July 2019

Published online: 24 July 2019

\section{References}

1. Gan D, Zhan M, Yang F, Zhang Q, Hu K, Xu W, Lu Q, Zhang L, Liang D. Expression analysis of argonaute, dicer-like, and RNA-dependent RNA polymerase genes in cucumber (Cucumis sativus L.) in response to abiotic stress. J Genet. 2017;96(2):235-49.

2. Wang JW, Wang LJ, Mao YB, Cai WJ, Xue HW, Chen XY. Control of root cap formation by MicroRNA-targeted auxin response factors in Arabidopsis. Plant Cell. 2005;17(8):2204-16.

3. Zhao B, Liang R, Ge L, Li W, Xiao H, Lin H, Ruan K, Jin Y. Identification of drought-induced microRNAs in rice. Biochem Biophys Res Commun. 2007:354(2):585-90.

4. Fahlgren N, Howell MD, Kasschau KD, Chapman EJ, Sullivan CM, Cumbie JS, Givan SA, Law TF, Grant SR, Dangl JL, et al. Highthroughput sequencing of Arabidopsis microRNAs: evidence for frequent birth and death of MIRNA genes. PLoS One. 2007;2(2):e219.

5. Jung $\mathrm{HJ}$, Kang $\mathrm{H}$. Expression and functional analyses of microRNA417 in Arabidopsis thaliana under stress conditions. Plant Physiol Biochem. 2007; 45(10-11):805-11.

6. Mlotshwa S, Pruss GJ, Vance V. Small RNAs in viral infection and host defense. Trends Plant Sci. 2008;13(7):375-82.

7. Carbonell A. Plant ARGONAUTEs: features, functions, and unknowns. Methods Mol Biol. 2017;1640:1-21.

8. Ma Z, Zhang X. Actions of plant Argonautes: predictable or unpredictable? Curr Opin Plant Biol. 2018:45(Pt A:59-67.

9. Morel JB, Godon C, Mourrain P, Beclin C, Boutet S, Feuerbach F, Proux $F$, Vaucheret $H$. Fertile hypomorphic ARGONAUTE (ago1) mutants impaired in post-transcriptional gene silencing and virus resistance. Plant Cell. 2002:14(3):629-39.

10. Zhai L, Sun W, Zhang K, Jia H, Liu L, Liu Z, Teng F, Zhang Z. Identification and characterization of Argonaute gene family and meiosis-enriched Argonaute during sporogenesis in maize. J Integr Plant Biol. 2014:56(11):1042-52.

11. Kapoor M, Arora R, Lama T, Nijhawan A, Khurana JP, Tyagi AK, Kapoor S. Genome-wide identification, organization and phylogenetic analysis of dicer-like, Argonaute and RNA-dependent RNA polymerase gene families and their expression analysis during reproductive development and stress in rice. BMC Genomics. 2008;9:451.

12. Zhang $H$, Xia R, Meyers BC, Walbot V. Evolution, functions, and mysteries of plant ARGONAUTE proteins. Curr Opin Plant Biol. 2015; 27:84-90.

13. Sun W, Xiang X, Zhai L, Zhang D, Cao Z, Liu L, Zhang Z. AGO18b negatively regulates determinacy of spikelet meristems on the tassel central spike in maize. J Integr Plant Biol. 2018:60(1):65-78.

14. Kidner CA, Martienssen RA. Spatially restricted microRNA directs leaf polarity through ARGONAUTE1. Nature. 2004:428(6978):81-4.

15. Yang L, Huang W, Wang H, Cai R, Xu Y, Huang H. Characterizations of a hypomorphic argonaute1 mutant reveal novel AGO1 functions in Arabidopsis lateral organ development. Plant Mol Biol. 2006;61(1-2):63-78.

16. Wu L, Zhang Q, Zhou H, Ni F, Wu X, Qi Y. Rice MicroRNA effector complexes and targets. Plant Cell. 2009;21(11):3421-35.

17. Qu F, Ye X, Morris TJ. Arabidopsis DRB4, AGO1, AGO7, and RDR6 participate in a DCL4-initiated antiviral RNA silencing pathway negatively regulated by DCL1. Proc Natl Acad Sci U S A. 2008;105(38):14732-7.

18. Azevedo J, Garcia D, Pontier D, Ohnesorge S, Yu A, Garcia S, Braun L, Bergdoll M, Hakimi MA, Lagrange T, et al. Argonaute quenching and global changes in dicer homeostasis caused by a pathogen-encoded GW repeat protein. Genes Dev. 2010;24(9):904-15.

19. Liu C, Xin Y, Xu L, Cai Z, Xue Y, Liu Y, Xie D, Liu Y, Qi Y. Arabidopsis ARGONAUTE 1 binds chromatin to promote gene transcription in response to hormones and stresses. Dev Cell. 2018; 44(3):348-361.e347. 
20. Dolata J, Bajczyk M. Salt Stress Reveals a New Role for ARGONAUTE1 in miRNA Biogenesis at the Transcriptional and Posttranscriptional Levels. Plant Physiol. 2016;172(1):297-312.

21. Moussian B, Schoof $H$, Haecker A, Jurgens G, Laux T. Role of the ZWILLE gene in the regulation of central shoot meristem cell fate during Arabidopsis embryogenesis. EMBO J. 1998;17(6):1799-809.

22. Zhu H, Hu F, Wang R, Zhou X, Sze SH, Liou LW, Barefoot A, Dickman $M$, Zhang $X$. Arabidopsis Argonaute10 specifically sequesters miR166/ 165 to regulate shoot apical meristem development. Cell. 2011; 145(2):242-56.

23. Ji L, Liu X, Yan J, Wang W, Yumul RE, Kim YJ, Dinh T, Liu J, Cui X, Zheng $B$, et al. ARGONAUTE10 and ARGONAUTE1 regulate the termination of floral stem cells through two microRNAs in Arabidopsis. PLoS Genet. 2011;7(3):e1001358.

24. Tucker MR, Okada T, Hu Y, Scholefield A, Taylor JM, Koltunow AM. Somatic small RNA pathways promote the mitotic events of megagametogenesis during female reproductive development in Arabidopsis. Development. 2012;139(8):1399-404.

25. Brosseau C, Moffett P. Functional and genetic analysis identify a role for Arabidopsis ARGONAUTE5 in antiviral RNA silencing. Plant Cell. 2015; 27(6):1742-54

26. Wang X-B, Jovel J, Udomporn P, Wang Y, Wu Q, Li W-X, Gasciolli V, Vaucheret $H$, Ding S-W. The 21-nucleotide, but not 22-nucleotide, viral secondary small interfering RNAs direct potent antiviral defense by two cooperative Argonautes inArabidopsis thaliana. Plant Cell. 2011;23(4):1625-38.

27. Harvey J, Lewsey MG, Patel K, Westwood J, Heimstadt S, Carr JP, Baulcombe DC. An antiviral defense role of AGO2 in plants. PLoS One. 2011;6(1):e14639.

28. Zhang X, Zhao H, Gao S, Wang WC, Katiyar-Agarwal S, Huang HD, Raikhel N, Jin H. Arabidopsis Argonaute 2 regulates innate immunity via miRNA393( *)-mediated silencing of a Golgi-localized SNARE gene, MEMB12. Mol Cell. 2011:42(3):356-66.

29. Jaubert M, Bhattacharjee S, Mello AF, Perry KL, Moffett P. ARGONAUTE2 mediates RNA-silencing antiviral defenses against potato virus $X$ in Arabidopsis. Plant Physiol. 2011;156(3):1556-64.

30. Zhang Z, Liu X, Guo X, Wang XJ, Zhang X. Arabidopsis AGO3 predominantly recruits 24-nt small RNAs to regulate epigenetic silencing. Nat Plants. 2016;2(5):16049.

31. Hunter C, Sun H, Poethig RS. The Arabidopsis heterochronic gene ZIPPY is an ARGONAUTE family member. Curr biol. 2003;13(19):1734-9.

32. Duan CG, Zhang H, Tang K, Zhu X, Qian W, Hou YJ, Wang B, Lang Z, Zhao $Y$, Wang $X$, et al. Specific but interdependent functions for Arabidopsis AGO4 and AGO6 in RNA-directed DNA methylation. EMBO J. 2015;34(5):581-92.

33. Eun C, Lorkovic ZJ, Naumann U, Long Q, Havecker ER, Simon SA, Meyers BC, Matzke AJ, Matzke M. AGO6 functions in RNA-mediated transcriptional gene silencing in shoot and root meristems in Arabidopsis thaliana. PLoS One 2011;6(10):e25730.

34. Hamera S, Song X, Su L, Chen X, Fang R. Cucumber mosaic virus suppressor 2b binds to AGO4-related small RNAs and impairs AGO4 activities. Plant J. 2012;69(1):104-15.

35. Hamera S, Yan Y, Song X, Chaudhary SU, Murtaza I, Su L, Tariq M, Chen X, Fang R. Expression of Cucumber mosaic virus suppressor $2 b$ alters FWA methylation and its siRNA accumulation in Arabidopsis thaliana. Biol Open. 2016;5(11):1727-34.

36. Takeda A, Iwasaki S, Watanabe T, Utsumi M, Watanabe $Y$. The mechanism selecting the guide strand from small RNA duplexes is different among argonaute proteins. Plant Cell Physiol. 2008;49(4):493-500.

37. Pradhan M, Pandey P, Gase K, Shraff M, Singh RK, Sethi A, Baldwin IT, Pandey SP. Argonaute 8 (AGO8) mediates the elicitation of primary defense against herbivory. Plant Physiol. 2017. https://doi.org/10.1104/pp.17.00702.

38. Olmedo-Monfil V, Durán-Figueroa N, Arteaga-Vázquez M, Demesa-Arévalo E, Autran D, Grimanelli D, Slotkin RK, Martienssen RA, Vielle-Calzada J-P. Control of female gamete formation by a small RNA pathway in Arabidopsis. Nature. 2010;464(7288):628-32.

39. Durán-Figueroa N, Vielle-Calzada J-P. ARGONAUTE9-dependent silencing of transposable elements in pericentromeric regions of Arabidopsis. Plant Signal Behav. 2010;5(11):1476-9.

40. Wu J, Yang Z, Wang Y, Zheng L, Ye R, Ji Y, Zhao S, Ji S, Liu R, Xu L, et al. Viral-inducible Argonaute18 confers broad-spectrum virus resistance in rice by sequestering a host microRNA. eLife. 2015;4:e05733
41. Wu J, Yang R, Yang Z, Yao S, Zhao S, Wang Y, Li P, Song X, Jin L, Zhou T, et al. ROS accumulation and antiviral defence control by microRNA528 in rice. Nat Plants. 2017:3:16203.

42. Xu D, Yang H, Zou C, Li WX, Xu Y, Xie C. Identification and functional characterization of the AGO1 ortholog in maize. J Integr Plant Biol. 2016; 58(8):749-58.

43. Yang $Y$, Zhong J, Ouyang YD, Yao J. The integrative expression and co-expression analysis of the AGO gene family in rice. Gene. 2013; 528(2):221-35.

44. Livak KJ, Schmittgen TD. Analysis of relative gene expression data using real-time quantitative PCR and the 2(-Delta Delta $C(T))$ method. Methods. 2001;25(4):402-8.

\section{Publisher's Note}

Springer Nature remains neutral with regard to jurisdictional claims in published maps and institutional affiliations.
Ready to submit your research? Choose BMC and benefit from:

- fast, convenient online submission

- thorough peer review by experienced researchers in your field

- rapid publication on acceptance

- support for research data, including large and complex data types

- gold Open Access which fosters wider collaboration and increased citations

- maximum visibility for your research: over $100 \mathrm{M}$ website views per year

At BMC, research is always in progress.

Learn more biomedcentral.com/submissions 